\title{
Implementation of Risk Management in Apartments Development Projects
}

\author{
Akromul Khaidar*, Firda Rahmawati, Mayasir Aziza, Sidik Ismanu \\ Accounting Department \\ State Polytechnic of Malang \\ Malang, Indonesia \\ *akromulk@gmail.com, firdarahmawati1331@gmail.com, mayasiraziza19@gmail.com
}

\begin{abstract}
Risk is difficult to predict in construction projects, so it requires a risk analysis. The first risk analysis carried out is the identification of risks to the project. This research uses qualitative methods and risk assessment and to makes a risk register. The results showed that the company carried out mitigation at certain stages, especially at extreme risk and high risk, which needed special attention because this risk would significantly impact project implementation. After mitigation, projects that have a high level of risk and inherent probability have decreased.
\end{abstract}

\section{Keywords—risk management, risk register, construction risk}

\section{INTRODUCTION}

Apartments are considered as one of the residential solutions in densely populated areas. This is because the building is designed in a vertical direction to be occupied by many families while saving land use. Risk can give influence to the productivity, performance, quality, and cost limits of the project. Risk can be said to be a result that may occur unexpectedly. Even though the activity has been planned, it is still uncertain that it will run entirely after the plan. However, the risks in construction projects cannot be eliminated but can be reduced or transferred from one party to another. In the construction of construction projects, many uncertainties are difficult to predict, so a risk analysis is needed.

Considering that ladder work is a structural element that is no less important in building projects. Besides, doing ladder work innovation is more flexible because it does not have an extreme impact on all construction elements in a project. One of the creations made in the Tamansari Equine apartment development project, Pulomas Park Center, East Jakarta, is to redesign a conventional emergency staircase into a precast staircase construction system. In this paper, research will be conducted on how to apply risk management in apartment development projects.

Risk can be defined as the opportunity for an adverse event to occur due to the uncertainty of what will be faced. Delay is a potential change that will happen in the future due to the inability to know what will happen if an activity is carried out; Chapman and Ward [1] emphasized that it is imperative to place uncertainty as a starting point in risk management. According to Pertiwi et al. [2], risk can be defined as the opportunity for an adverse event to occur due to the uncertainty of what will be faced. Project risk is an event or condition that, if it happens, can have a positive or negative effect on one or many project objectives [3].

Risk management includes implementing risk management planning, identification, analysis, risk response planning, and controlling risks in the project. Project risk management aims to increase the likelihood of festive project events and reduce the probability of adverse project events [3].

In ISO 31000-2018, the processes in risk management are:

- Communication and consultation

- Scope, context, and criteria

- Risk assessment:

- Monitoring and review

- Recording and reporting

The objectives of this Risk Management System Procedure are:

- I was directing and providing guidance on risk management to be applied to this company so that it can further increase the guarantee of achieving the Vision, Mission, Goals, Strategies, and Targets of the Company.

- Risk Management creates Risk Management value that contributes to the achievement of demonstrable and improved goals, such as health and safety reputation, legal and regulatory compliance, public acceptance, environmental protection, financial performance, product quality, efficiency in operations, and corporate and human governance.

A construction project is a series of activities carried out only once and are generally short-term and have a clear start and end time. In this series of activities, there is a process that processes project resources into actions in the form of 
buildings. The process that occurs in this series of activities certainly involves related parties, either directly or indirectly.

\section{METHODS}

This research uses applied research methods. The information obtained is the types of risks in apartment development projects in Jakarta. The chances are grouped based on the project life cycle, including the stages of planning, operation, conception, and execution.

\section{RESULTS AND DISCUSSION}

Risk management is an approach taken to risk, namely by understanding, identifying, and evaluating a project's chances. Then consider what will be done with the impact and the possibility of transferring risks to other parties or reducing the risks. Various sources can be used to identify risks correctly, such as records, practices, and experiences of other parties in similar or relevant companies, literature studies, or modeling. In identifying risks, this company refers to the Risk Register. The risk register is a list containing the entire recapitulation of all analysis work papers and the consequences of risks. The following is the risk register for an apartment building project.

TABLE I. RISK ASSESSMENT

\begin{tabular}{|l|l|l|l|}
\hline No. & \multicolumn{1}{|c|}{ Risk Events } & \multicolumn{1}{|c|}{ Root Cause } & \multicolumn{1}{c|}{ Impact } \\
\hline 1. & $\begin{array}{l}\text { Design foundation } \\
\text { used not eligible } \\
\text { resources bearing } \\
\text { capacity of actual } \\
\text { soil }\end{array}$ & $\begin{array}{l}\text { The ability of a } \\
\text { subcontractor } \\
\text { investigation of } \\
\text { the soil is less } \\
\text { qualified }\end{array}$ & $\begin{array}{l}\text { 1. Not in optimal } \\
\text { design foundation; } \\
\text { 2. Data on the geology } \\
\text { of the soil does not } \\
\text { represent. }\end{array}$ \\
\hline 2. & $\begin{array}{l}\text { The collapse of the } \\
\text { formwork } \\
\text { emergency stairs }\end{array}$ & $\begin{array}{l}\text { The broken } \\
\text { scaffold shoring } \\
\text { formwork }\end{array}$ & $\begin{array}{l}\text { 1. Work accident; } \\
\text { 2. Reputase company; } \\
\text { 3. Criminal; } \\
\text { Time of the } \\
\text { implementation is not } \\
\text { in accordance with the } \\
\text { contract }\end{array}$ \\
\hline 3. & $\begin{array}{l}\text { There is } \\
\text { interference } \\
\text { drill hole }\end{array}$ & $\begin{array}{l}\text { Landslide in the } \\
\text { hole }\end{array}$ & $\begin{array}{l}\text { The project is not } \\
\text { completed } \\
\text { accordance with the } \\
\text { contract }\end{array}$ \\
\hline
\end{tabular}

TABLE II. THE LEVEL OF RISK INHERENT

\begin{tabular}{|c|c|c|c|c|c|}
\hline No. & Risk Events & Probability & Impact & Score & $\begin{array}{c}\text { The Level } \\
\text { Of Risk }\end{array}$ \\
\hline \multirow[t]{3}{*}{1.} & $\begin{array}{l}\text { Design of } \\
\text { foundation } \\
\text { used not } \\
\text { qualified } \\
\text { power } \\
\text { bearing } \\
\text { capacity of } \\
\text { soil, } \\
\text { actual the }\end{array}$ & $4=$ Large & $\begin{array}{l}4= \\
\text { Large }\end{array}$ & 16 & $\begin{array}{l}\text { EXTREME } \\
\text { HIGH }\end{array}$ \\
\hline & $\begin{array}{l}\text { The collapse } \\
\text { of the } \\
\text { formwork } \\
\text { emergency } \\
\text { stairs }\end{array}$ & $\begin{array}{l}3 \\
\text { Medium }\end{array}$ & $\begin{array}{l}4= \\
\text { Large }\end{array}$ & 12 & $\begin{array}{l}\text { HIGH } \\
\text { RISK }\end{array}$ \\
\hline & $\begin{array}{l}\text { Sliding in the } \\
\text { hole }\end{array}$ & $2=$ Small & $\begin{array}{l}2= \\
\text { Small }\end{array}=$ & 4 & $\begin{array}{l}\text { MEDIUM } \\
\text { RISK }\end{array}$ \\
\hline
\end{tabular}

TABLE III. RISK MANAGEMENT

\begin{tabular}{|c|c|c|c|c|}
\hline No. & $\begin{array}{c}\text { RISK } \\
\text { EVENTS }\end{array}$ & $\begin{array}{c}\text { RISK } \\
\text { OWNER }\end{array}$ & $\begin{array}{c}\text { MITIGATION } \\
\text { ACTIONS }\end{array}$ & $\begin{array}{c}\text { THE COST } \\
\text { OF } \\
\text { MITIGATION } \\
\text { (IDR) }\end{array}$ \\
\hline 1. & $\begin{array}{l}\text { The design } \\
\text { of the } \\
\text { foundation } \\
\text { that } \\
\text { executive } \\
\text { used not } \\
\text { eligible } \\
\text { resources } \\
\text { bearing } \\
\text { capacity of } \\
\text { actual soil }\end{array}$ & $\begin{array}{l}\text { Chief } \\
\text { Executive }\end{array}$ & $\begin{array}{l}\text { 1. Selection of } \\
\text { subcon an } \\
\text { expert in the } \\
\text { field of soil } \\
\text { investigation } \\
\text { 2. The selection } \\
\text { of subcon ever } \\
\text { conduct an } \\
\text { investigation }\end{array}$ & 125.000 .000 \\
\hline 2. & $\begin{array}{l}\text { The } \\
\text { collapse of } \\
\text { the } \\
\text { formwork } \\
\text { emergency } \\
\text { stairs }\end{array}$ & $\begin{array}{l}\text { Chief } \\
\text { Executive }\end{array}$ & $\begin{array}{l}\text { Checking and } \\
\text { maintenance of } \\
\text { scaffolding that } \\
\text { will be use as } \\
\text { the blowtorch }\end{array}$ & 367.454 \\
\hline 3. & $\begin{array}{l}\text { Sliding in } \\
\text { hole }\end{array}$ & $\begin{array}{l}\text { Chief } \\
\text { Executive }\end{array}$ & $\begin{array}{l}\text { 1. Use some } \\
\text { casing; } \\
2 . \quad \text { Use of } \\
\text { bentonite with a } \\
\text { sufficient } \\
\text { amount }\end{array}$ & 109.239 .000 \\
\hline
\end{tabular}

Table 1-3 are the risk register, there is risk assessment, the level of risk inherent, and risk management. There is an identification of risks that may occur in a construction project if it is seen that the lowest risk is at the construction stage. Based on table 2 , the risk during the construction phase that often occurs is a disturbance in the drill hole. This is the highest risk occurs at the construction stage. The problem that can often happen is the foundation design that does not meet the soil bearing capacity requirements. Then another high risk occurs at the implementation stage. this risk that rarely happens in projects is the collapse of the emergency staircase formwork. 
At this stage, the necessary mitigation measures will be identified to minimize the consequences of these risks. Sources of risk with a fairly large percentage of the extreme risk and high risk are safety and the environment. The construction process, in general, is an activity that carries a lot of risks. As the responsible party in the field for the duration of the construction, the project management team must support and implement programs that can guarantee or minimize work accidents or preventive measures. After being mitigated, projects with a high-risk level with an inherent probability of $70 \%$ decreased to $25 \%$ with a mitigation cost of $\mathrm{Rp}$ $105,307,250$, and the risk level also decreased. The secondhigh risk with a probability of $50 \%$ after mitigation decreases to $20 \%$ with a mitigation cost of Rp. $38,038,800$. It can be seen in the inherent table below.

\section{CONCLUSION}

It is imperative to carry out risk management in every construction project to avoid losses on the project cost, quality, and schedule. Risks that are classified as extreme risk and high risk based on the source of the most considerable risk, namely those with the largest percentage, are $70 \%$ classified as extreme risk and 50\% classified as high risk. This states that apartment building project planning is not planned in detail, causing errors or inappropriate implementation. Handling risks classified as extreme risk and high risk based on the source of risk, namely redesigning the foundation design and checking and maintaining tools.

\section{REFERENCES}

[1] C. Chapman and S. Ward, Project Risk Management. West Sussex: John Willey \& Sons Ltd. 2003.

[2] I.G.A.I.M. Pertiwi, W.S. Kristinayanti, and I.G.M.A. Aryawan, "Gatoto Subroto Denpasar Underpass Development Project Risk Management,' Journal of Accounting, Economics and Business Management, vol. 4, no. 1, pp. 1- 6, 2016.

[3] Project Management Body Of Knowledge, Sixth Edition, A Guide to The Project Management Body of Knowledge, Project Management Institute. 2017. 